\title{
Thermal and Microstructure Characterization of Zn-Al-Si Alloys and Chemical Reaction with Cu Substrate During Spreading
}

\author{
Katarzyna Berent, Janusz Pstruś, and Tomasz Gancarz
}

\author{
(Submitted November 15, 2015; in revised form April 13, 2016; published online April 28, 2016)
}

\begin{abstract}
The problems associated with the corrosion of aluminum connections, the low mechanical properties of $\mathrm{Al} /$ $\mathrm{Cu}$ connections, and the introduction of $\mathrm{EU}$ directives have forced the potential of new materials to be investigated. Alloys based on eutectic $\mathrm{Zn}-\mathrm{Al}$ are proposed, because they have a higher melting temperature $\left(381^{\circ} \mathrm{C}\right)$, good corrosion resistance, and high mechanical strength. The $\mathrm{Zn}$-Al-Si cast alloys were characterized using differential scanning calorimetry (DSC) measurements, which were performed to determine the melting temperatures of the alloys. Thermal linear expansion and electrical resistivity measurements were performed at temperature ranges of -50 to $250{ }^{\circ} \mathrm{C}$ and 25 to $300{ }^{\circ} \mathrm{C}$, respectively. The addition of $\mathrm{Si}$ to eutectic $\mathrm{Zn}$-Al alloys not only limits the growth of phases at the interface of liquid solder and $\mathrm{Cu}$ substrate but also raises the mechanical properties of the solder. Spreading test on Cu substrate using eutectic $\mathrm{Zn}$-Al alloys with $0.5,1.0,3.0$, and $5.0 \mathrm{wt}$.\% of $\mathrm{Si}$ was studied using the sessile drop method in the presence of QJ201 flux. Spreading tests were performed with contact times of 1, 8, 15, 30, and 60 min, and at temperatures of $475,500,525$, and $550{ }^{\circ} \mathrm{C}$. After cleaning the flux residue from solidified samples, the spreadability of $\mathrm{Zn}$-Al-Si on $\mathrm{Cu}$ was determined. Selected, solidified solder/substrate couples were crosssectioned, and the interfacial microstructures were studied using scanning electron microscopy and energy dispersive $x$-ray spectroscopy. The growth of the intermetallic phase layer was studied at the solder/substrate interface, and the activation energy of growth of $\mathrm{Cu}_{5} \mathrm{Zn}_{8}, \mathrm{CuZn}$, and $\mathrm{CuZn}$ phases were determined.
\end{abstract}

Keywords microstructure, spreading, thermal and mechanical properties, Zn-Al-Si

\section{Introduction}

The $\mathrm{Zn}-\mathrm{Al}$ eutectic system has been proposed as an alternative to soldering at high-temperatures, with a maximum working temperature is up to $350{ }^{\circ} \mathrm{C}(\operatorname{Ref} 1)$. This alloy has many desirable characteristics, including low cost, high mechanical properties, and good thermal and electrical conductivities. However, the $\mathrm{Zn}-\mathrm{Al}$ alloy demonstrates very weak wettability of substrates and oxidation resistance, which could be eliminated by the addition of $\mathrm{Cu}(\operatorname{Ref} 2), \mathrm{Ag}(\operatorname{Ref} 3)$, and $\mathrm{Mg}$ (Ref 4). Many authors have investigated the effects of different

This article is an invited submission to JMEP selected from presentations at the Symposium "Wetting and High-Temperature Capillarity," belonging to the Topic "Joining and Interfaces" at the European Congress and Exhibition on Advanced Materials and Processes (EUROMAT 2015), held on September 20-24, 2015, in Warsaw, Poland, and has been expanded from the original presentation.

Katarzyna Berent, AGH University of Science and Technology, Academic Centre for Materials and Nanotechnology, Krakow, Poland; and Janusz Pstruś and Tomasz Gancarz, Institute of Metallurgy and Materials Science, Polish Academy of Sciences, Krakow, Poland. Contact e-mails: kasia.berent@gmail.com and kberent@agh.edu.pl.

chemical and metallurgical aspects on the impact properties of Zn-Al alloys (Ref 2-9). In this study, the effects of Si addition on the microstructure and mechanical properties of the $\mathrm{Zn}-\mathrm{Al}$ alloy were examined.

However, the mechanical properties of the binary $\mathrm{Zn}-\mathrm{Al}$ alloys are not suitable for most engineering applications. Silicon is the most important alloying element used in the majority of cast alloys (Ref 9). It is responsible for a good castability (due to its high fluidity), it has very low solubility in aluminum alloys, and therefore it precipitates as virtually pure $\mathrm{Si}$ particles, which improve the strength. A small addition of $\mathrm{Si}$ caused stress resistance to increase in the tensile test (Ref 6, 7). $\mathrm{Si}$ content also led to increased wear resistance and hardness (Ref 7, 8) in Zn-Al-Si alloys. Jian et al. (Ref 9) showed that the wear rate of alloys containing 2 wt.\% silicon instead of copper was approximately 10 times lower than the wear rate of the Zn27Al alloy.

The possibility of using $\mathrm{Zn}-\mathrm{Al}$ alloys to solder $\mathrm{Al} / \mathrm{Cu}$ (Ref $10), \mathrm{Al} / \mathrm{Mg}$ (Ref 11), Al/steel (Ref 12), and $\mathrm{Cu} / \mathrm{Cu}(\operatorname{Ref} 13)$ extend their applications in industry. However, there are few studies showing the impact of temperature and time on phenomena occurring at the interface of liquid solder and the solid substrate. In (Ref 14 ), $\mathrm{Al} / \mathrm{Cu}$ and $\mathrm{Cu} / \mathrm{Cu}$ joints soldered by eutectic $\mathrm{Zn}-\mathrm{Al}$ are shown; from $\mathrm{Cu}$ side, three intermetallic compounds (IMCs) from the $\mathrm{Cu}-\mathrm{Zn}$ system of $\mathrm{CuZn}, \mathrm{Cu}_{5} \mathrm{Zn}_{8}$, and $\mathrm{CuZn}_{4}$ phases were present at the interface. The addition of $\mathrm{Ag}$ and $\mathrm{Cu}$ to $\mathrm{Zn}-\mathrm{Al}$ alloys (Ref 2, $3,14,15)$ caused the growth of the IMC layer at the interface to be blocked. According to the results of this work, the effects of $\mathrm{Si}$ addition on the kinetics of formation and growth of the $\mathrm{CuZn}, \mathrm{Cu}_{5} \mathrm{Zn}_{8}$, and $\mathrm{CuZn}_{4}$ phases in the spreading process were studied. 


\section{Experimental}

The cast alloys of $\mathrm{Zn}-\mathrm{Al}$ with $0.5,1.0,3.0$, and 5.0 wt.\% of $\mathrm{Si}$ were prepared in a glove box filled with high purity $\mathrm{Ar}$ (99.9999 vol.\%), from equally high purity $99.999 \%$ of $\mathrm{Al}, \mathrm{Si}$, and $\mathrm{Zn}$ elements in $\mathrm{Al}_{2} \mathrm{O}_{3}$ crucibles. The samples for electrical resistivity tests were sucked into quartz capillaries, and for the mechanical tests were casted into graphite molds. Spreading tests on $\mathrm{Cu}$ substrate of eutectic $\mathrm{Zn} 5.3 \mathrm{Al}$ alloys with $0.5,1.0$, and 3.0 wt. $\%$ of Si were performed using the sessile drop (SD) method. A more detailed description of the experimental apparatus can be found in the earlier work of Moser et al. (Ref 18). Spreading tests were carried out in the presence of QJ201 flux and without protective atmosphere at temperatures of $475,500,525$, and $550{ }^{\circ} \mathrm{C}$, in order to determine the activation energy of the phase forming. Therefore, flux QJ201 from powder, consisting of $\mathrm{KCl} 50, \mathrm{LiCl} 32, \mathrm{NaF} 10$, and $\mathrm{ZnCl}_{2}$ 8 (wt.\%), was applied for the purposes of protection and oxide removal. In order to determine the kinetics of growth of the IMCs, the tests were performed at $500{ }^{\circ} \mathrm{C}$ for spreading times of $1,8,15,30$, and $60 \mathrm{~min}$. As described in (Ref 2, 3), the spreading areas of $0.5 \mathrm{~g}$ samples of $\mathrm{Zn}-\mathrm{Al}-\mathrm{Si}$ solder were calculated after cleaning the flux residue from solidified samples, and the spreadability of $\mathrm{Zn}-\mathrm{Al}-\mathrm{Si}$ alloys on $\mathrm{Cu}$ was determined in accordance with ISO 9455-10:2013-03. Selected solder/substrate couples were cut perpendicular to the plane of the interface on a diamond wire saw, mounted in conductive resin, ground, polished, and subjected to microstructure and elemental analysis using FEI Quanta 3D FEG scanning electron microscope (SEM) coupled with energy dispersive $\mathrm{x}$-ray spectrometry (EDS), in order to study the interfacial microstruc- ture and the IMCs occurring at interface, the same as described in (Ref 2, 3). The SEM-EDS measurements were performed at an accelerating voltage of $15 \mathrm{kV}$. The growth rate and activation energy of $\mathrm{CuZn}, \mathrm{Cu}_{5} \mathrm{Zn}_{8}$, and $\mathrm{CuZn}_{4}$ layers in the solid state were determined. Thermal analysis of $\mathrm{Zn}-\mathrm{Al}-\mathrm{xSi}$ alloys was carried out at temperatures up to $500{ }^{\circ} \mathrm{C}$ in an argon gas flow at $40 \mathrm{~mL} / \mathrm{min}$, with a heating rate of $10{ }^{\circ} \mathrm{C} / \mathrm{min}$, using differential scanning calorimetry (DSC). The alloys were measured to verify the CTE and thermal deformation in the temperature range from -50 to $250{ }^{\circ} \mathrm{C}$, with a heating rate of $5{ }^{\circ} \mathrm{C} / \mathrm{min}$ under a helium $5 \mathrm{~N}$ gas flow of $20 \mathrm{~mL} / \mathrm{min}$, using a thermal mechanical analyzer (TMA). Electrical resistivity measurements were made using the four-point method with a Keithley 6220 as the current source (output $100 \mathrm{~mA}$ with an accuracy of $10 \mu \mathrm{A}$ ) coupled with a Keithley 2182 nanovoltmeter $(10 \mathrm{mV}$ range with an accuracy of $1 \mathrm{nV}$ ) at temperatures ranging from 25 to $300{ }^{\circ} \mathrm{C}$, with heating steps of $10^{\circ} \mathrm{C}$ during a $180 \mathrm{~min}$ under air. The mechanical properties of the $\mathrm{Zn}-\mathrm{Al}-\mathrm{Si}$ alloys were evaluated using an INSTRON 6025 testing machine modernized by Zwick/Roell.

\section{Results and Discussion}

\subsection{Characteristics of Cast Alloys}

3.1.1 Microstructures. The microstructures of the Zn-Al$\mathrm{xSi}$ alloys in the as-cast state consist mainly of three phases. One has a bright contrast, the second has a lighter gray color, and the third is darker, as shown in Fig. 1. EDS analysis was carried out on these points. The phase with bright contrast (point A) is a zinc-rich phase containing about 98.9 wt.\% $\mathrm{Zn}$.

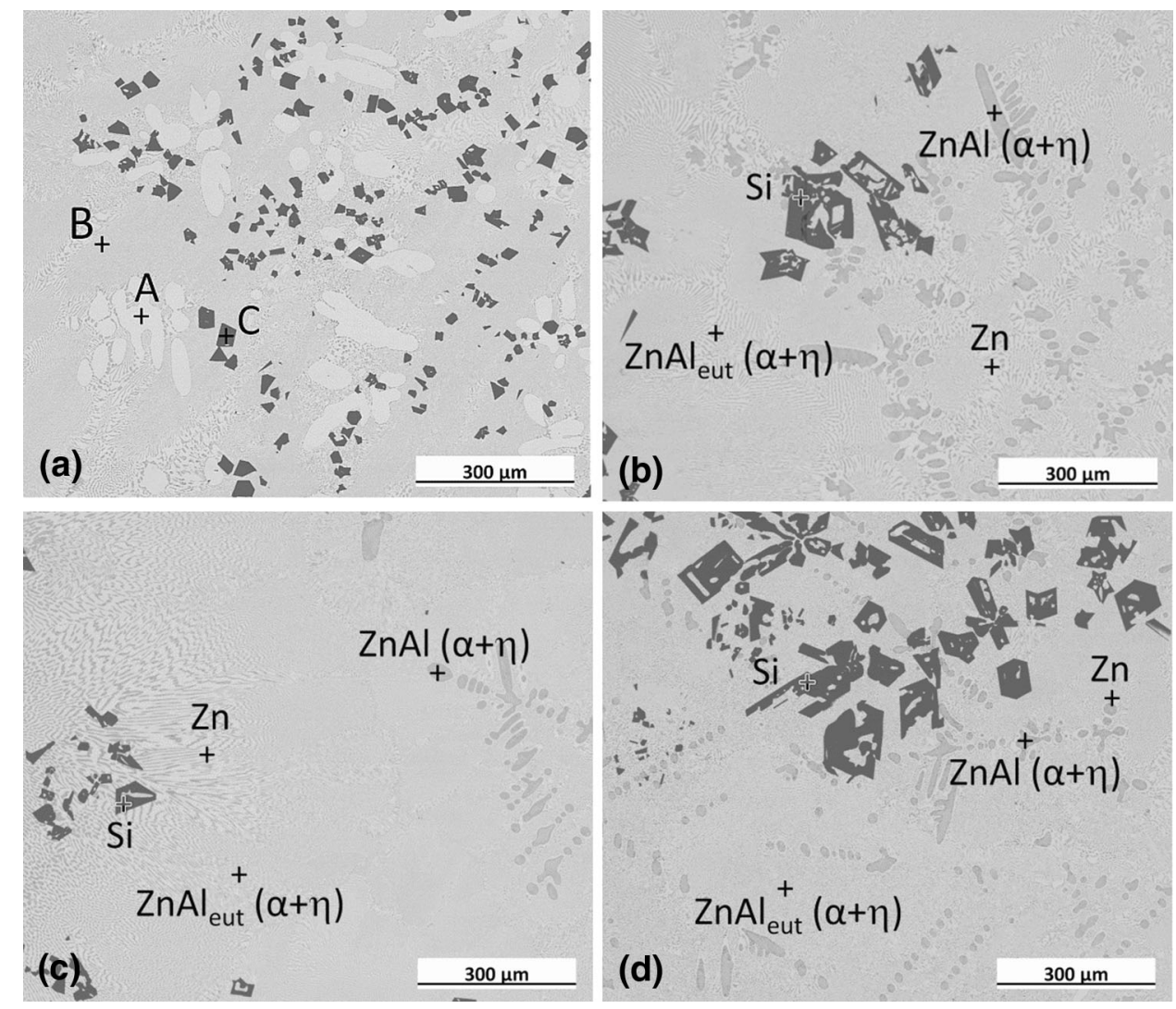

Fig. 1 Microstructure of the as-cast $\mathrm{Zn}-\mathrm{Al}$ alloys with different amounts of Si: (a) 0.5, (b) 1.0, (c) 3.0, and (d) 5.0 wt.\% 


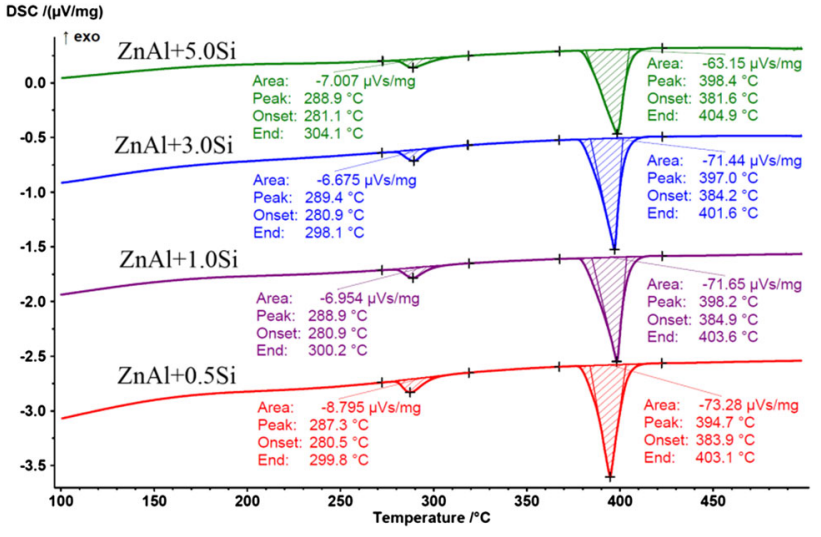

Fig. 2 The DSC curves of the Zn-Al-xSi as-cast alloys

The gray eutectic phase (point B) was found to be an aluminum-rich phase containing about $22.4 \mathrm{wt} . \%$ Al. In addition, some particles with darker appearance (point C) were observed at different places containing only Si. The addition of silicon had not formed the IMCs, only caused occurring $\mathrm{Si}$ particles on the microstructure of the $\mathrm{Zn}-\mathrm{Al}$ alloy. The solubility of silicon in the zinc-aluminum matrix is nearly zero (Ref 20). Therefore, silicon solidifies into the primary and eutectic silicon particles in the microstructure of the $\mathrm{Zn}-\mathrm{Al}-\mathrm{Si}$ alloys (Ref 6-9). The distribution of Si particles is non-uniform in the alloys. As can be seen in Fig. 1(a-c), the microstructure of $\mathrm{Zn}-\mathrm{Al}-\mathrm{Si}$ consists of eutectic colonies of an Al-rich phase and $\mathrm{Zn}$-rich phase formed at the eutectic and Si particles. In the $\mathrm{Zn}-\mathrm{Al}-0.5 \mathrm{Si}$ alloy, the microstructure displays primary crystals of the $\mathrm{Zn}$ phase with a dendritic morphology, and an $\alpha+\eta$ eutectic phase distributed in the interdendritic space (Fig. 1a). The primary $\mathrm{Zn}$ phases were surrounded by eutectic phases, in which fine eutectic Si platelets were found to be dispersed in eutectic $\mathrm{Zn}$ matrix. The silicon particles are smaller, and their distribution is more uniform, compared to the other alloys. As illustrated in Fig. 1(b)-(d), when 1.0-5.0 wt.\% Si is added to the $\mathrm{Zn}-\mathrm{Al}$ matrix, in the eutectic $\mathrm{Zn}-\mathrm{Al}$ microstructure increasing amount of $\mathrm{Si}$ particles. The composition of the light contrasted areas indicates a $\mathrm{Zn}$-rich phase $(\eta-\mathrm{Zn})$, and the darker areas represent the Al-rich phase. Additionally, an AlZn-rich compound occurs at the expense of the Zn-rich phase. With increased silicon content, the size of the Si particles also increases, and their distribution becomes non-uniform. The eutectic silicon particles can be seen in the area of the Zn-rich phase and the phase mixture for all alloys. Similar observations were determined by Vencl et al. (Ref 8), where the primary Zn area increased with decreasing Si content.

3.1.2 Thermal Properties. The DSC melting curves of $\mathrm{Zn}-\mathrm{Al}-\mathrm{xSi}$ alloys are presented in Fig. 2. The addition of Si had inconsiderable on the melting temperature of $\mathrm{Zn}-\mathrm{Al}-\mathrm{xSi}$ solder. The DSC results demonstrated two obvious endothermic peaks

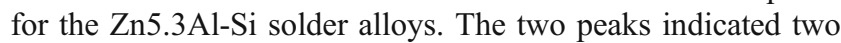
steps in the melting process of Zn-Al-Si solder. Based on the Zn-Al-Si phase diagram (Ref 15), for the first endothermic peak, at $\sim 281{ }^{\circ} \mathrm{C}$, the first reaction was a solid solution from the $\alpha$ - to the $\alpha$-phases, where the reaction of the Al-rich facecentered cubic (fcc) and hexagonal close-packed (hcp) phase was observed to convert to a Zn-rich phase of fcc crystal structure. The second endothermic peak appeared at $\sim 384{ }^{\circ} \mathrm{C}$, where the reaction was melting of eutectic $\mathrm{Zn}-\mathrm{Al}$. The addition

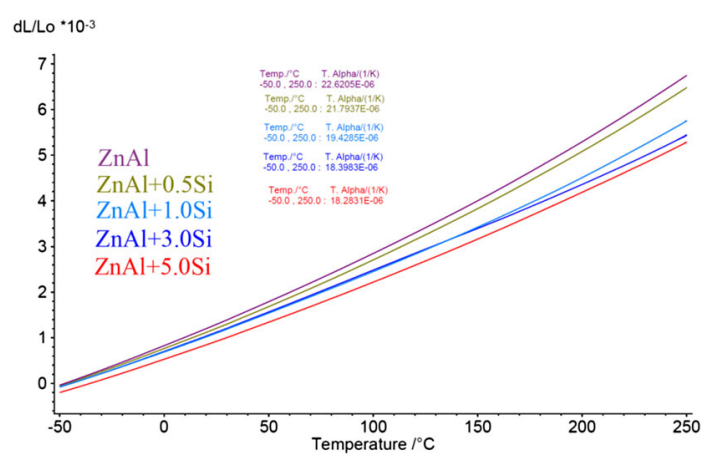

Fig. 3 TMA results of thermal expansion measurements vs. temperature

of silicon to alloys causes slight differences between melting and solidification temperature. As shown in Fig. 2, increasing the concentration of silicon contributes to an increased melting point. According to Takaku et al. (Ref 15) and Gancarz et al. (Ref 2, 3), all Zn-Al solders show two endothermic peaks, and both reactions take place at approximately the same temperature.

3.1.3 Thermal Expansion. Increasing electrical power density requires solder with excellent mechanical properties, high reliability, and stability, because higher electric power results in higher heat flux and, therefore, leads to a higher operating temperature for electronic equipment. The thermal expansion mismatch between components grows larger due to differences in their coefficients of thermal expansion (CTE), and causes a great enough strain in solder to induce fatigue failure mode (Ref 1). The results of thermal expansion measurements are shown in Fig. 3. The CTE was calculated in the present study at the range of -50 to $250{ }^{\circ} \mathrm{C}$. At the beginning, the thermal expansion coefficients of all Zn-Al-xSi solders are essentially the same value, although the values are significantly lower than for eutectic $\mathrm{Zn}-\mathrm{Al}$ solder. The CTE are 21.79, 19.43, 18.38, and $18.29\left(\times 10^{-6} \mathrm{~K}^{-1}\right)$ for $0.5,1.0,3.0$, and $5.0 \mathrm{wt} . \% \mathrm{Si}$, respectively, showing that the CTE decreases as Si content increases. The Zn-Al-Si alloys have lower CTE than $\mathrm{Zn}-\mathrm{Al}$ alloys $\left(22.6 \times 10^{-6} \mathrm{~K}^{-1}\right)$ and Pb-based solder alloys $\left(30.0 \times 10^{-6} \mathrm{~K}^{-1}\right)$. In their complementary work, Gancarz et al. (Ref 16) found that the thermal expansion was higher for $\mathrm{Zn}$-Al-In than for $\mathrm{Pb}-5 \mathrm{Sn}$, despite the fact that the In dissolves in $\mathrm{Zn}-\mathrm{Al}$ and does not create an IMC. In the case of Zn-Al-Si alloys, reducing CTE by increasing $\mathrm{Si}$ content reduces differences between $\mathrm{Cu}\left(16.9 \times 10^{-6} \mathrm{~K}^{-1}\right)$ (Ref 19) and solder, causing fewer cracks in working joints during temperature changes.

3.1.4 Electrical Resistivity. The temperature dependence of the electrical resistivity $(\rho)$ for the $\mathrm{Zn}-\mathrm{Al}-\mathrm{Si}$ solders was measured, as shown in Fig. 4. As can be seen, the resistivity of $\mathrm{Zn}-\mathrm{Al}-\mathrm{Si}$ alloys increases linearly with increasing temperature. Alloys with high silicon content exhibit higher electrical resistance. The values of resistivity measurements range from 7.2 to $7.6 \mu \Omega \mathrm{cm}$ at room temperature. This can be related to the microstructure of the sample. The presence of a higher amount of the eutectic phase is the reason of higher electrical resistivity. Gancarz et al. (Ref 3,16) found that the electrical resistivity of $\mathrm{Zn}-\mathrm{Al}-\mathrm{In}$ and $\mathrm{Zn}-\mathrm{Al}-\mathrm{Ag}$ increases as temperature rises and different metal components are added: from 6.5 to $8.5 \mu \Omega \mathrm{cm}$ at room temperature for Zn-Al-xIn $(x=0.5$ 1.5 wt. $\%$ ) and $6.5-7.2 \mu \Omega \mathrm{cm}$ for $\mathrm{Zn}-\mathrm{Al}$ with addition of $\mathrm{Ag}$ 


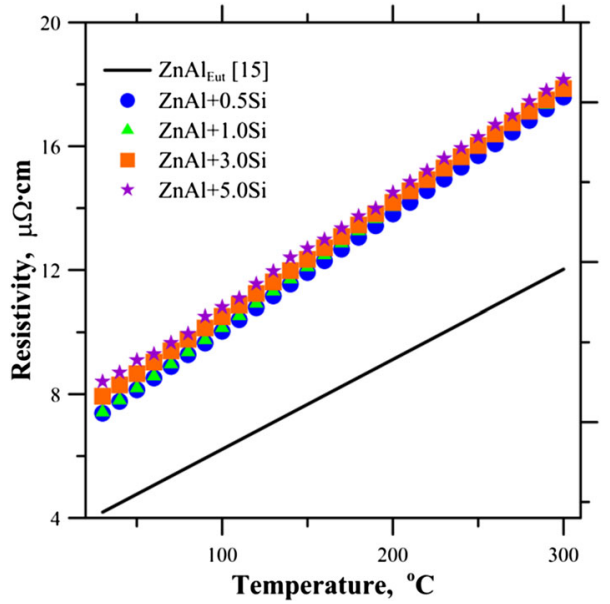

Fig. 4 Electrical resistivity of Zn-Al alloys with different Si contents

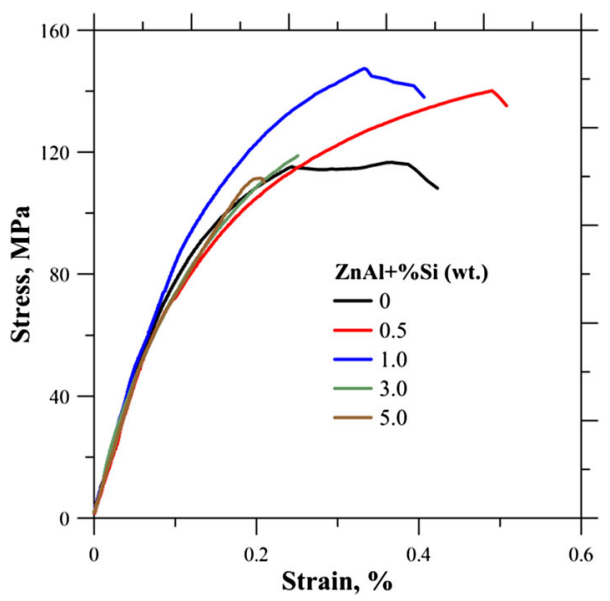

Fig. 5 The stress-strain curves of Zn-Al-xSi solder alloy

from 0.5 to 1.5 wt. $\%$. But all values are greater than the values of $\rho$ obtained for the eutectic Zn-Al alloy $(5.0 \mu \Omega \mathrm{cm})$, and lower than those of a $\mathrm{Sn}-37 \mathrm{~Pb}$ solder $(14.25 \mu \Omega \mathrm{cm})(\operatorname{Ref} 16)$.

3.1.5 Mechanical Properties. Tensile test was used to evaluate the mechanical properties of the as-cast $\mathrm{Zn}-\mathrm{Al}-\mathrm{Si}$ alloys compared with the strength of eutectic $\mathrm{ZnAl}$ solder. Figure 5 shows the stress-strain curve of Zn-Al-Si alloys. It was found that the tensile strength of $\mathrm{Zn}-\mathrm{Al}-\mathrm{Si}$ alloys increased with increasing silicon content above $1.5 \mathrm{wt} . \%$ (Ref 17). The alloys with 0.5 and 1.0 wt. $\%$ Si content showed sufficiently high tensile strength of 144 and $147(\mathrm{MPa})$, respectively. When the amount of silicon increases above $5.0 \mathrm{wt} . \%$, the tensile strength decreases. The brittleness of coarse silicon crystals (both eutectic and primary silicon) is the main reason for the poor mechanical properties of ZA alloys. The strength of $\mathrm{Zn}-\mathrm{Al}$ 3.0 $\mathrm{Si}$ and $\mathrm{Zn}-\mathrm{Al}-5.0 \mathrm{Si}$ alloys is greatly reduced, to 118 and 110 $(\mathrm{MPa})$, respectively. The elongation to failure of $\mathrm{Zn}-\mathrm{Al}-\mathrm{Si}$ alloys was very low, even lower than that for $\mathrm{Pb}-5 \mathrm{Sn}(39 \%)$, and had an effect on the preparation of samples, and the condition and temperature treatment of samples after casting. The tensile properties correlated to the microstructural behavior as a function of element contents. This may be related to a
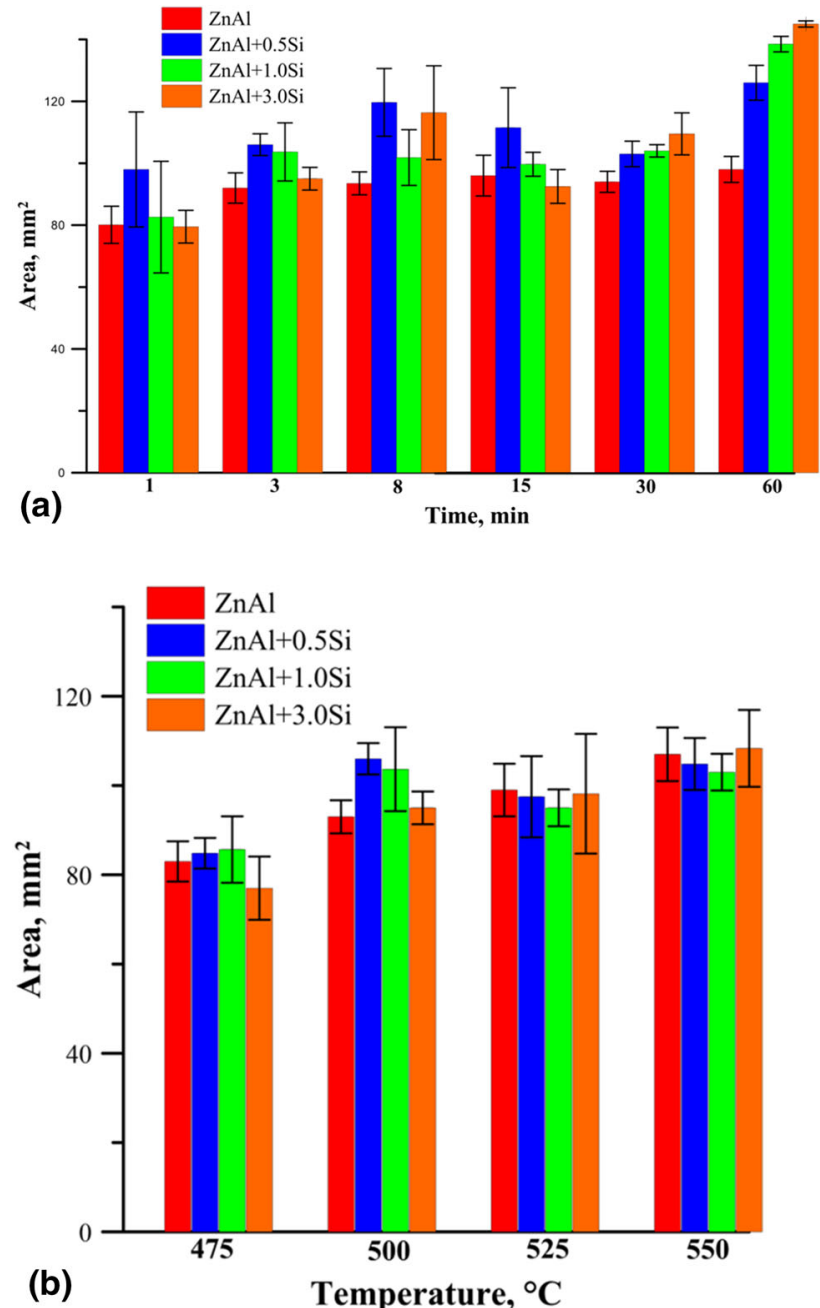

Fig. 6 Effect of silicon on spreading area of $\mathrm{ZnAl}$ solder on $\mathrm{Cu}$ substrate for different (a) times, (b) temperatures

Table 1 The results of EDS analysis of the IMC layers formed at the $\mathrm{Zn}-\mathrm{Al}-\mathrm{Si} / \mathrm{Cu}$

\begin{tabular}{lll}
\hline IMCs & Cu (at.\%) & Zn (at.\%) \\
\hline $\mathrm{Zn}-\mathrm{Al}-0.5 \mathrm{Si}$ & & \\
$\beta-\mathrm{CuZn}$ & $48.8 \pm 1.0$ & $51.2 \pm 1.0$ \\
$\gamma-\mathrm{Cu}_{5} \mathrm{Zn}_{8}$ & $41.0 \pm 0.8$ & $59.0 \pm 1.2$ \\
$\varepsilon-\mathrm{CuZn}{ }_{4}$ & $19.5 \pm 0.8$ & $80.5 \pm 1.2$ \\
$\mathrm{Zn}-\mathrm{Al}-1.0 \mathrm{Si}$ & & \\
$\beta-\mathrm{CuZn}$ & $48.9 \pm 1.0$ & $51.1 \pm 1.0$ \\
$\gamma-\mathrm{Cu}_{5} \mathrm{Zn}$ & $42.3 \pm 0.9$ & $57.7 \pm 1.2$ \\
$\varepsilon-\mathrm{CuZn}$ & $19.6 \pm 0.8$ & $80.4 \pm 1.6$ \\
$\mathrm{Zn}-\mathrm{Al}-3.0 \mathrm{Si}$ & & \\
$\beta-\mathrm{CuZn}$ & $47.4 \pm 1.0$ & $52.6 \pm 1.1$ \\
$\gamma-\mathrm{Cu}_{5} \mathrm{Zn}_{8}$ & $42.3 \pm 0.9$ & $57.7 \pm 1.2$ \\
$\varepsilon-\mathrm{CuZn}_{4}$ & $21.0 \pm 0.4$ & $79.0 \pm 1.6$ \\
\hline
\end{tabular}

change of eutectic composition with the increase of silicon content and the creation of primary Si particles. Savaskan et al. (Ref 6) show that the addition of a small amount of Si into $\mathrm{Zn} 15 \mathrm{Al}-\mathrm{Cu}$ alloys can greatly enhance their mechanical 
properties. This result shows that silicon can be an alternative element to cooper. When the content of silicon is more than $1 \mathrm{wt} . \%$, it was found that the trend reverses.

3.1.6 Spreading Test. Results of the spreading area $A$ of $\mathrm{Zn}$-Al-xSi alloys on $\mathrm{Cu}$ substrate after different times of contact $(1,8,15,30$, and $60 \mathrm{~min})$ and temperatures $(475,500,525$, and $550{ }^{\circ} \mathrm{C}$ ) are shown in Fig. 6(a)-(b). The droplet area of the molten $\mathrm{Zn}-\mathrm{Al}$-xSi alloys is larger than those of the eutectic Zn$\mathrm{Al}$ alloy. The maximum spreading area was obtained for $\mathrm{Zn}-\mathrm{Al}$ $0.5 \mathrm{Si}$ for varying periods of time ranging from 1 to $15 \mathrm{~min}$. The spreading area of $\mathrm{Zn}-\mathrm{Al}-0.5 \mathrm{Si}$ was $98 \mathrm{~mm}^{2}$ for $1 \mathrm{~min}$. For 1.0 and $3.0 \mathrm{wt} . \% \mathrm{Si}$ content, the area of contact is lower than those for 0.5 wt. $\%$ Si content, being 82 and $79 \mathrm{~mm}^{2}$ for $1 \mathrm{~min}$. For these two compositions, the increase of time from 30 to $60 \mathrm{~min}$
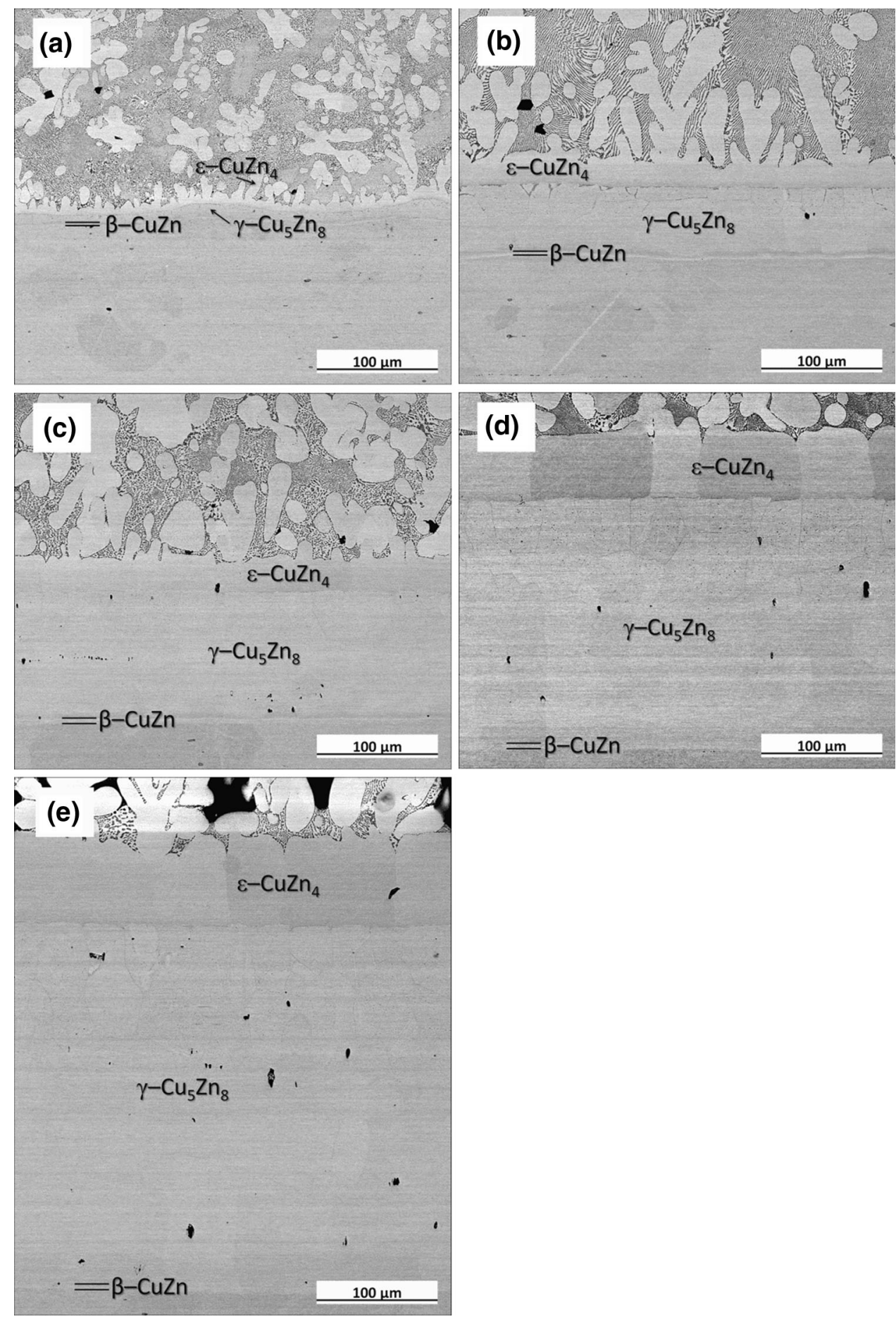

Fig. 7 Backscattered SEM micrographs showing the microstructure of IMCs between $\mathrm{Zn}-\mathrm{Al}-0.5 \mathrm{Si}$ and $\mathrm{Cu}$ substrate at $500{ }^{\circ} \mathrm{C}$ at different times: (a) 1 (b) 8, (c) 15, (d) 30, and (e) 60 min, respectively 

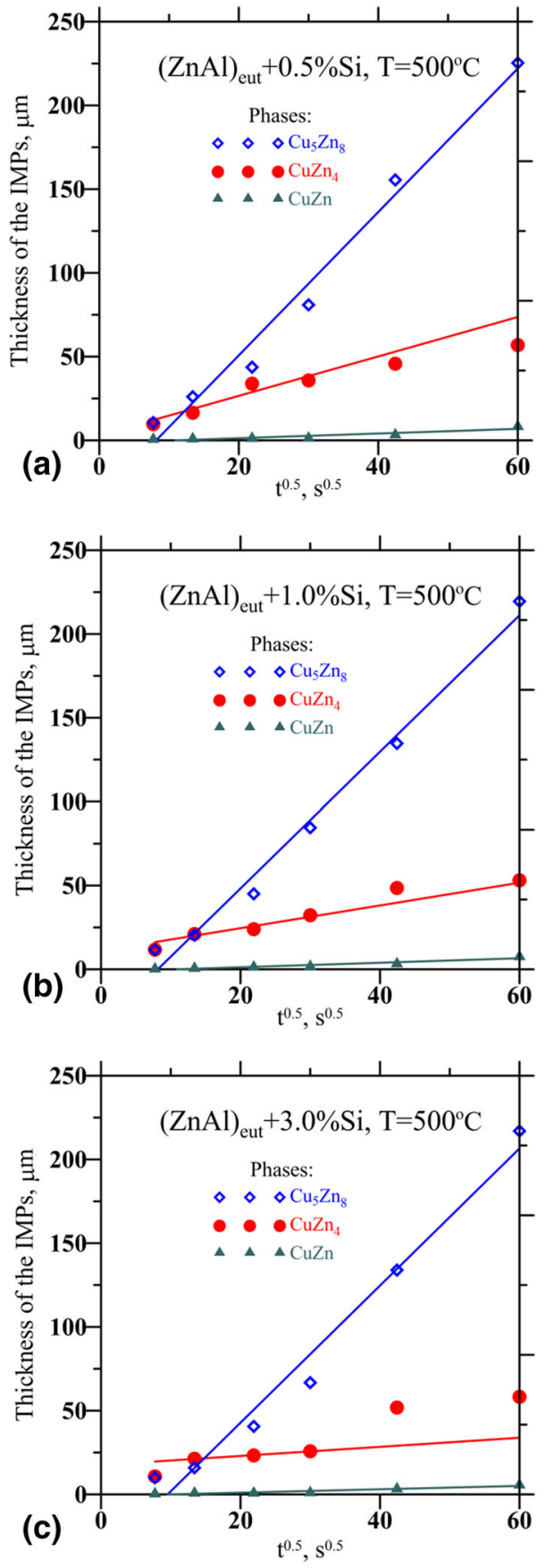

Fig. 8 Plots of thickness vs. square root of time for IMCs formed at interfaces in the $\mathrm{Zn}-\mathrm{Al}-\mathrm{xSi} / \mathrm{Cu}$ samples during the reflow process at $500{ }^{\circ} \mathrm{C}$ for: (a) 0.5 , (b) 1.0 , and (c) 3.0 wt. $\% \mathrm{Si}$

results in higher contact area. However, further increase of time to $30 \mathrm{~min}$ leads, for $\mathrm{Zn}-\mathrm{Al}-0.5 \mathrm{Si}$, to a insignificant decrease of area. As contact time increased, the spreading area increased slowly.

Figure $6 \mathrm{~b}$ shows that the spreading area of the alloys increased as the temperature increased from 475 to $550{ }^{\circ} \mathrm{C}$. At $475{ }^{\circ} \mathrm{C}$, additional $\mathrm{Si}$ content, up to $1 \mathrm{wt} . \%$, resulted in a decreasing spreading area. A further temperature increase, to $525^{\circ} \mathrm{C}$, causes the area to decrease, and a temperature of $550{ }^{\circ} \mathrm{C}$ affects the growth of contact area from 95 to $103 \mathrm{~mm}^{2}$ for $\mathrm{Zn}-\mathrm{Al}-1.0 \mathrm{Si}$. It is shown that eutectic $\mathrm{Zn}-\mathrm{Al}$ and $\mathrm{Zn}-\mathrm{Al}-$
3.0Si have higher areas at 525 and $550{ }^{\circ} \mathrm{C}$. Increasing $\mathrm{Si}$ content up to $1 \mathrm{wt} . \%$ in the solder may lead to decreasing the spreading time of solder. It has to be noted that, with increasing temperature and time, the solder spreadability is improved, and the best results were obtained at $550{ }^{\circ} \mathrm{C}$. However, the spreadability of $\mathrm{Zn}-\mathrm{Al}-\mathrm{Si}$ is relatively poor compared to the high lead solder due to the oxygen affinity of $\mathrm{Zn}$ and Al. The addition of a small amount of $\mathrm{Cu}$ and $\mathrm{Ag}$ to $\mathrm{ZA}$ solder was investigated by Gancarz et al. (Ref 2, 3). It was observed that the spreading area obtained for eutectic $\mathrm{ZnAl}$ with $\mathrm{Cu}$ increased with increasing time, temperature, and $\mathrm{Cu}$ content. This can be compared to with the spreading area of $\mathrm{Zn}-\mathrm{Al}$ with $\mathrm{Ag}$, where the effect of time was very small, whereas the effect of temperature on spreading area was strong. Generally, the addition of $\mathrm{Ag}$ reduced the spreading area (Ref 3 ), but this effect was rather smaller compared to the increased spreading area in $\mathrm{Zn}-\mathrm{Al}$ with $\mathrm{Si}$ alloys.

3.1.7 Effect of Time on Chemical Reaction at Interface During Spreading. One of the present authors (Ref 3, 21) reports that three $\mathrm{Cu}-\mathrm{Zn}$ intermetallic compound layers were formed at $500{ }^{\circ} \mathrm{C}$, and that the processes occurring at the solder/substrate interface can be divided into three distinct stages. The first one involves the dissolution of copper by liquid zinc, the second the crystallizations, and the third the solid-state transformations. After the spreading treatment, the consumption of the $\mathrm{Cu}$ substrate by $\mathrm{Zn}$ was observed, and it was noted that three reaction layers $\left(\varepsilon-\mathrm{CuZn} n_{4}, \gamma-\mathrm{Cu}_{5} \mathrm{Zn}_{8}\right.$, and $\left.\beta-\mathrm{CuZn}\right)$ at the interface were formed, between the Zn-Al-xSi alloys and $\mathrm{Cu}$ substrate. The formation of these layers was confirmed by Takaku et al. (Ref 15) and Gancarz et al. (Ref 2, 3, 16). The ZnAl-based alloys are exceptional alloys forming peculiar IMCs with $\mathrm{Cu}$ due to the presence of $\mathrm{Zn}$, with dissolving inside $\mathrm{Al}$, which is in accordance with phase diagram Al-Cu-Zn (Ref 22). This is due to the fact that the highest growth of the IMC phase with time and temperature correlates to the stability of phases from the Al-Cu-Zn system (Ref 3 ). The ThermoCalc calculations show that the $\gamma$-phase that is $\mathrm{Cu}_{5} \mathrm{Zn}_{8}$ and $\mathrm{Al}_{4} \mathrm{Cu}_{9}$ (in the phase diagram of $\mathrm{Al}-\mathrm{Cu}-\mathrm{Zn}$ ) has the lowest Gibbs free energy. However, considering the time of the spreading process, the amount and availability of components are controlled by diffusion of $\mathrm{Cu}$ and $\mathrm{Zn}$ to the interface. Figure 7 shows backscattered electron (BSE) micrographs of the microstructure of $\mathrm{Zn}-\mathrm{Al}-0.5 \mathrm{Si}$ solder at $500{ }^{\circ} \mathrm{C}$, at times of (a) 1, (b) 8, (c) 15, (d) 30, and (e) $60 \mathrm{~min}$. A thin layer of CuZn forms close to the $\mathrm{Cu}$ side, a scallop-shaped $\mathrm{CuZn}_{4}$ layer forms at the solder side, and a $\mathrm{Cu}_{5} \mathrm{Zn}_{8}$ layer forms in the middle. The average thickness of layers was measured for different reflowing times. Inside the $\mathrm{Cu}_{5} \mathrm{Zn}_{8}$ layer, the fast path of $\mathrm{Cu}$ diffusion is shown, which is also observed in $\mathrm{Zn}-\mathrm{Al}$ with $\mathrm{Ag}$ and $\mathrm{Cu}$ alloys (Ref 3, 15, 21). The results of EDS quantitative analysis are summarized in Table 1. The composition of the three phases coincides well with the $\mathrm{CuZn}_{4}, \mathrm{Cu}_{5} \mathrm{Zn}_{8}$, and $\mathrm{CuZn}$ phase, even for the thicker one. As the content of Si increased, the fraction of the $\mathrm{CuZn}_{4}$ phase decreased (due to the diffusion of $\mathrm{Zn}$ toward the solder interface and controlled growth of interfacial IMCs). After eight minutes reflow, it was observed that the IMCs increased in thickness with reflow time. However, the growth rates of IMC layers had been somewhat reduced for the samples with higher $\mathrm{Si}$ content. The effect of $\mathrm{Cu}$ and $\mathrm{Ag}$ on the microstructure is in good agreement with results from previous studies in the most popular Zn-Al cast alloys (Ref 3), although there are inconsistencies in the influence of Si on the thickness of IMC (Ref 2, 3). 

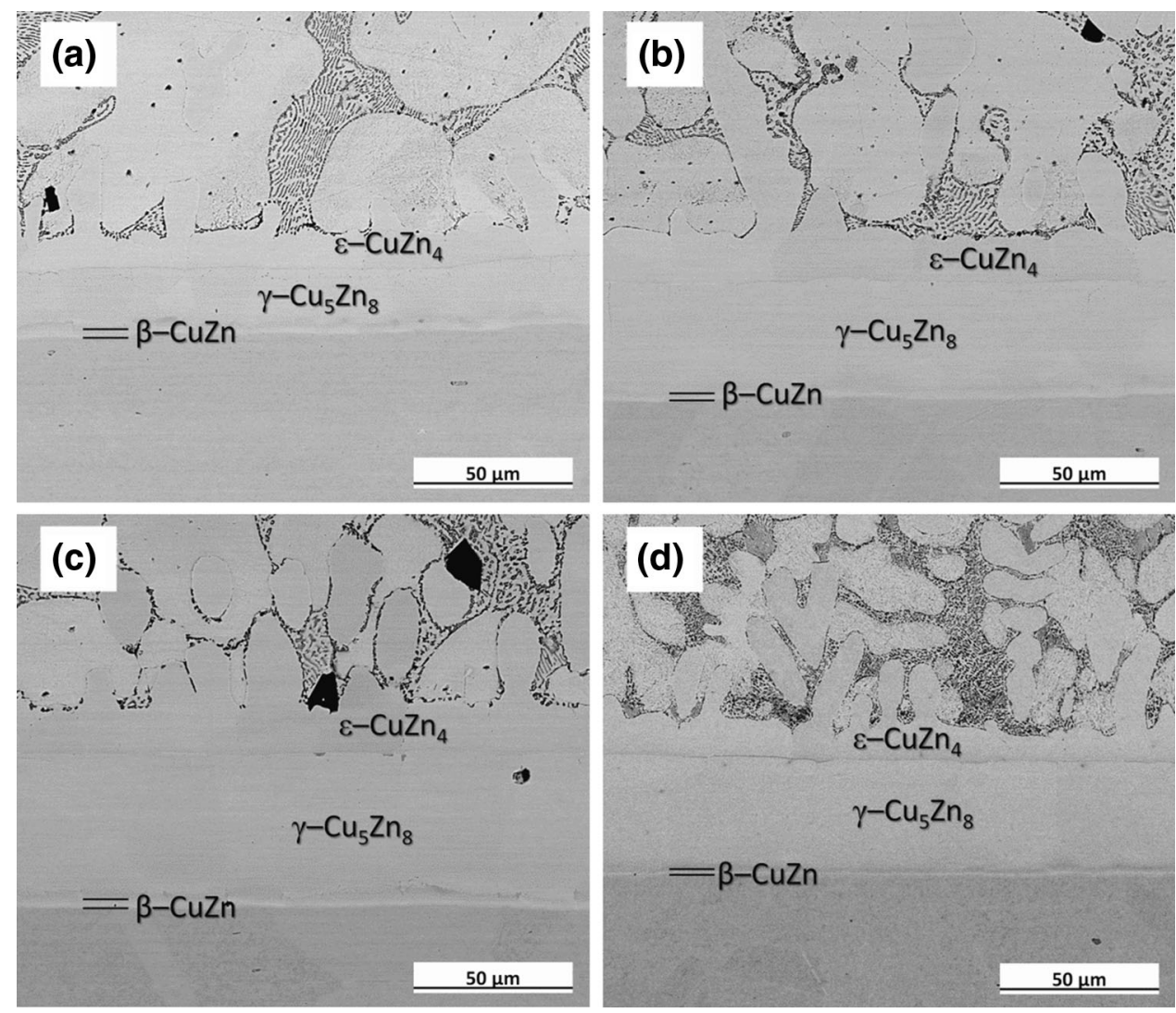

Fig. 9 Backscattered SEM micrographs showing the microstructure of IMCs between $\mathrm{Zn}-\mathrm{Al}-0.5 \mathrm{Si}$ and $\mathrm{Cu}$ substrate after 8 min at different temperatures: (a) 475 (b) 500 , (c) 525 , and (d) $550^{\circ} \mathrm{C}$, respectively

It was found that, when the $\mathrm{Ag}$ and $\mathrm{Cu}$ concentration was low $(0.5$ wt. $\%)$, the thickness of the interface layers was the smallest (Ref 3, 15).

3.1.8 Intermetallic Compound Thickness Analysis. Figure $8(\mathrm{a}),(\mathrm{b})$, and (c) presents the thickness of IMC layers formed at interface in temperature $500{ }^{\circ} \mathrm{C}$ and the time from 1 to $60 \mathrm{~min}$, for $\mathrm{Zn}-\mathrm{Al}$ with $\mathrm{Si}$ addition of $0.5,1.0$, and 3.0 wt. $\%$, respectively. In the beginning of spreading test from 1 to $8 \mathrm{~min}$, the thickness of $\mathrm{Cu}_{5} \mathrm{Zn}_{8}$ and $\mathrm{CuZn}_{4}$ layers is almost the same, and after $15 \mathrm{~min}$, the highest thickness was obtained for $\mathrm{Cu}_{5} \mathrm{Zn}_{8}$. Generally, at the interface of $\mathrm{Zn}$-Al solder with a $\mathrm{Cu}$ substrate, the three binary IMCs $\mathrm{CuZn}_{4}, \mathrm{Cu}_{5} \mathrm{Zn}_{8}$, and $\mathrm{CuZn}$ are observed, which is in accordance with the phase diagram of $\mathrm{Al}-\mathrm{Cu}-\mathrm{Zn}$. Taking into account the thickness of IMC layers and relationship between $d$ (the IMC thickness) and $t$ (time), the character of diffusion could be determined:

$$
\delta=k t^{n},
$$

where $k$ represents the growth rate coefficient for the consumption rate (experimental values). This means that the growth rate constant $k$ was determined from the slope of the linear relation in Fig. 8. The possibility description of time by square root are respond to the formation of the IMC layers for all investigated solders which is controlled by volume diffusion.

Takaku et al. (Ref 15) have reported that the addition of $1 \mathrm{wt} \% \mathrm{Cu}$ to $\mathrm{Zn}-\mathrm{Al}$ alloy causes activation energy to decrease and enhances the growth of the IMC layers. Different results were observed by Gancarz et al. (Ref 3$)$, who confirmed that the addition of 0.5 wt.\% $\mathrm{Ag}$ to $\mathrm{Zn} 5.3 \mathrm{Al}$ solder could effectively reduce the thickness of $\mathrm{Cu}_{5} \mathrm{Zn}_{8}$ and $\mathrm{CuZn}$ layers by lowering the diffusion rate of $\mathrm{Zn}$ in the $\mathrm{Cu}$ substrate. Grain boundary diffusion plays a major role in the formation of the new phase, compared to surface or bulk diffusion. Hence, the large primary $\mathrm{Si}$ particles that appeared near to the eutectic region and within the $\mathrm{Zn}$ matrix act as barriers to $\mathrm{Cu}$ and $\mathrm{Zn}$ diffusion along the grain boundaries to form $\mathrm{Cu}-\mathrm{Zn}$ IMCs. The average thickness of each IMC layer was measured for different times. Longer times correspond to greater IMC thickness. The thin $\beta-\mathrm{CuZn}$ layer was also reported in the literature $(\operatorname{Ref} 2,3,15)$.

3.1.9 Effect of Temperature on Chemical Reaction at Interface During Spreading. Figure 9 present a series of backscattered electron images illustrating the effect of temperature on the microstructure of the Zn-Al-0.5Si solder, after the spreading test for a time of $8 \mathrm{~min}$. Changes in the thickness and shape of the IMCs were registered at four different temperatures $\left(475,500,525\right.$, and $\left.550{ }^{\circ} \mathrm{C}\right)$. The microstructure of $\mathrm{Zn}$ Al-Si solder (Fig. 9) shows three IMC layers, $\mathrm{CuZn}_{4}, \mathrm{Cu}_{5} \mathrm{Zn}_{8}$, and $\mathrm{CuZn}$, which are formed at the $\mathrm{Cu}$ substrate-solder interface for all levels of Si content in $\mathrm{Zn}-\mathrm{Al}$ alloys. The $\mathrm{CuZn}$ intermetallic layer grows immediately on $\mathrm{Cu}$ substrate. The morphology of $\mathrm{CuZn}_{4}$ is a scallop-shaped layer, while those of $\mathrm{Cu}_{5} \mathrm{Zn}_{8}$ and $\mathrm{CuZn}$ are flat. The thin $\beta-\mathrm{CuZn}$ layer varies from about 0.4 to $1.5 \mu \mathrm{m}$, the $\gamma-\mathrm{Cu}_{5} \mathrm{Zn}_{8}$ layer from about 15.1 to $39.5 \mu \mathrm{m}$, and the $\varepsilon-\mathrm{CuZn}_{4}$ layer from about 11.5 to $26.2 \mu \mathrm{m}$ for $\mathrm{Zn}-\mathrm{Al}-0.5 \mathrm{Si}$, depending on temperature. Such reaction morphologies are quite similar to those of $\mathrm{Zn}-\mathrm{Al}-\mathrm{Cu}$ and $\mathrm{Zn}-\mathrm{Al}-\mathrm{Ag}$ (Ref 2, 3). For the present reaction layers, it can be said that $\mathrm{Cu}$ 

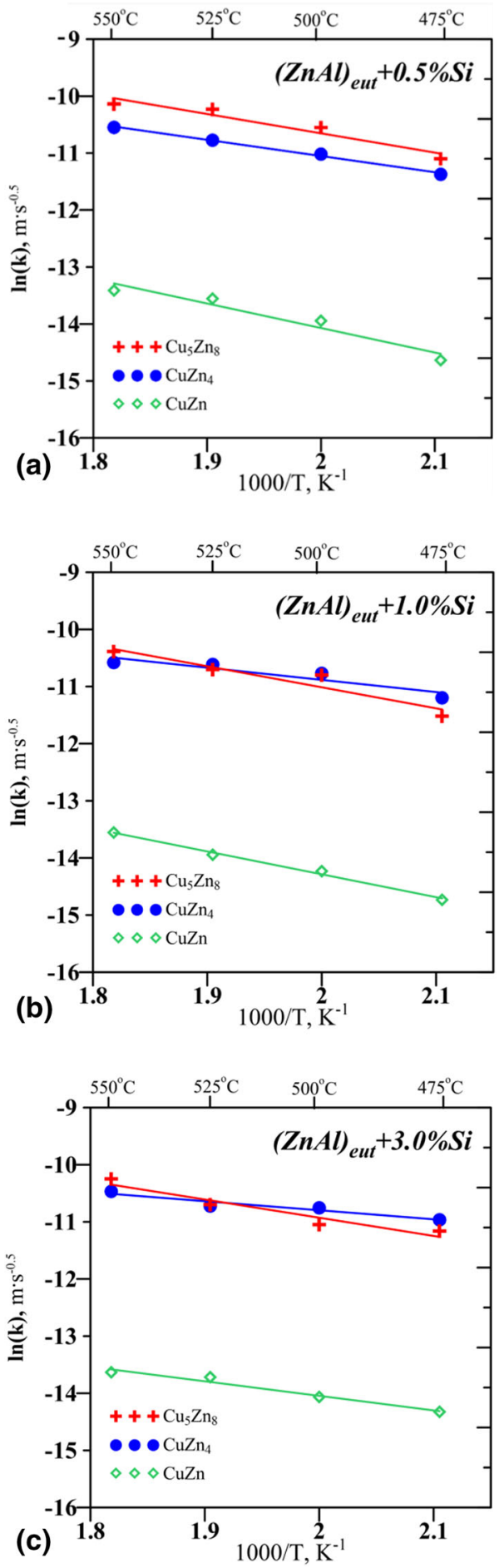

Fig. 10 Arrhenius plot for the growth of the total interfacial $\mathrm{Zn}-\mathrm{Al}$ xSi solder for (a) 0.5 , (b) 1.0 , and (c) $3.0 \mathrm{wt} . \% \mathrm{Si}$

dissolution into the liquid solder forms the scallop-shaped $\mathrm{CuZn}_{4}$ layer. In this case, the $\mathrm{Cu}$ is predominantly transported to molten solder along the $\mathrm{CuZn}_{4}$ grain boundaries during spreading. Higher spreading temperatures correspond to thicker IMCs.
Table 2 The activation energy of IMCs of $\mathrm{ZnAl}$ alloys with $\mathrm{Si}$ content after spreading

\begin{tabular}{lcc}
\hline Alloys (wt.\%) & IMCs & Activation energy Q, kJ/mol \\
\hline Zn-Al (Ref 2) & $\mathrm{CuZn}$ & 32.38 \\
& $\mathrm{Cu}_{5} \mathrm{Zn}_{8}$ & 42.38 \\
& $\mathrm{CuZn}_{4}$ & 29.54 \\
Zn-Al-0.5Si & $\mathrm{CuZn}$ & 35.77 \\
& $\mathrm{Cu}_{5} \mathrm{Zn}_{8}$ & 28.18 \\
& $\mathrm{CuZn}_{4}$ & 23.65 \\
Zn-Al-1.0Si & $\mathrm{CuZn}$ & 33.27 \\
& $\mathrm{Cu}_{5} \mathrm{Zn}_{8}$ & 30.62 \\
& $\mathrm{CuZn}_{4}$ & 17.34 \\
Zn-Al-3.0Si & $\mathrm{CuZn}$ & 21.18 \\
& $\mathrm{Cu}_{5} \mathrm{Zn}_{8}$ & 26.50 \\
& $\mathrm{CuZn}_{4}$ & 13.15 \\
\hline
\end{tabular}

3.1.10 Kinetics of Growth of the IMC Layers. Since IMC growth is a diffusion-dominated process, the growth rate for interface migration can be described by an Arrhenius equation as follows:

$$
k=k_{0} \cdot \exp ^{-\frac{Q}{R T}},
$$

where $k_{0}$ is the migration rate constant, $Q$ is the activation energy, $R$ is the universal gas constant, and $T$ is the absolute temperature. Figure 10 shows the $\ln k$ versus $(1 / T)$ plots for individual phases for $\mathrm{Zn}-\mathrm{Al}$ alloys with $\mathrm{Si}$ addition of 0.5 , 1.0 , and $3.0 \mathrm{wt} . \%$, respectively. The activation energy values were calculated from the slopes of the Arrhenius plot using a linear regression model derived from Fig. 10(a)-(c). The activation energies of $\mathrm{Zn}-\mathrm{Al}-\mathrm{Si}$ are summarized in Table 2. The slops of the lines in Fig. 10 suggest higher activation energy for $\gamma-\mathrm{Cu}_{5} \mathrm{Zn}_{8}$ and $\beta-\mathrm{CuZn}$ than for $\varepsilon-\mathrm{CuZn}_{4}$. Accordingly, it can be predicted that the first intermetallic phase to be formed at the interface between the $\mathrm{Zn}$ solder and $\mathrm{Cu}$ substrate is $\mathrm{CuZn}_{4}$. The apparent activation energies calculated for the growth of $\beta, \gamma$, and $\varepsilon$ were $33.27,30.62$, and $17.34 \mathrm{~kJ} / \mathrm{mol}$ for $\mathrm{Zn}-\mathrm{Al}-1.0 \mathrm{Si}$ are similar to those of $\mathrm{Zn}-\mathrm{Al}-1.0 \mathrm{Cu}$ (Ref 15), at 48,36 , and $16 \mathrm{~kJ} / \mathrm{mol}$, respectively. However, slightly lower compare to eutectic $\mathrm{Zn}-\mathrm{Al}$ alloy for $\beta, \gamma$, and $\varepsilon$ were $32.38,42.38$, and $29.54 \mathrm{~kJ} / \mathrm{mol}$ (Ref 3). As the activation energy of IMCs increases, the formation and growth of this compound becomes more difficult. On the other hand, low activation energies indicate easier IMC formation and growth. Addition of less than $3.0 \mathrm{wt} . \% \mathrm{Si}$ to eutectic $\mathrm{Zn}$-Al increases the activation energy of IMCs which inhibits their nucleation and growth. Data obtained by Gancarz et al. (Ref 2), for a $\mathrm{Zn}-\mathrm{Al}-\mathrm{Cu} / \mathrm{Cu}$ interface, show lower activation energy than the data collected by Takaku (Ref 15). In line with (Ref 3), the addition of $\mathrm{Ag}$ to eutectic $\mathrm{Zn}-\mathrm{Al}$ also increases activation energy to 49,37 , and $17 \mathrm{~kJ} / \mathrm{mol}$ for $\beta, \gamma$, and $\varepsilon$, respectively. In all cases, the addition of a small amount of metal content increases the activation energy of IMCs, which inhibits the nucleation and growth of IMC layers.

\section{Conclusion}

The present study is concerned with the effects of silicon addition on the microstructures, and electrical and mechanical 
properties of $\mathrm{Zn}-\mathrm{Al}$ solder alloys. The following conclusions can be drawn:

1. The microstructure of cast alloys consists of both eutectic and primary Si particles. For $\mathrm{Zn}-\mathrm{Al}$ alloys containing less than $1.0 \mathrm{wt} . \% \mathrm{Si}$, the microstructure was blocky and showed a homogeneous distribution of primary particles. The eutectic Si had a mostly fibrous morphology, which became much larger in size in the alloys containing more than 1.0 wt.\% Si.

2. The DSC results demonstrated that the addition of 0.5 , $1.0,3.0$, and 5.0 wt.\% Si changes the melting temperatures slightly. Melting occurred over a slightly higher range of temperatures.

3. From TMA analysis, the linear average coefficient of thermal expansion (CTE) was found. Meanwhile, a small amount of $0.5-1.0$ wt.\% $\mathrm{Si}$, added to a eutectic $\mathrm{ZnAl}$ alloy, results in an appreciable change in thermal and mechanical properties.

4. The results of electrical resistivity measurements show that the addition of $\mathrm{Si}$ to eutectic $\mathrm{ZnAl}$ increases the electrical resistivity in the range from 7.2 to $7.6 \mu \Omega \mathrm{cm}$ at room temperature for $\mathrm{Zn}-\mathrm{Al}-\mathrm{xSi}(x=0.5-3.0 \mathrm{wt} . \%)$.

5. Tensile test results indicate that adding a small amount of Si can clearly improve the strength and ductility, but the trend reverses above $1.0 \mathrm{wt} . \%$. The decrease in tensile strength can be explained by the increased amount of large silicon particles.

6. The formation of three IMC layers, such as $\mathrm{CuZn}$, $\mathrm{Cu}_{5} \mathrm{Zn}_{8}$, and $\mathrm{CuZn}$, was observed at the solder/Cu substrate interface. The results show that the addition of $\mathrm{Si}$ can reduce the activation energy of the intermetallic phases. But the growth rate of the $\mathrm{CuZn}_{4}$ phase decreased due to the diffusion of $\mathrm{Zn}$ toward the solder interface and the growth of interfacial IMCs was controlled by the amount of Si. The IMC layers became thinner as Si content increased. As shown earlier, the spreadability and the thickness of the IMC layers increase at higher temperatures and longer spreading times.

7. The experimental results presented in this paper demonstrated that a small amount of silicon causes general refinement of microstructure and better mechanical properties.

\section{Acknowledgment}

This work was financed by the Minister of Science and High Education of Poland Grant IP2014 011473, in the years 2015 to 2017.

\section{Open Access}

This article is distributed under the terms of the Creative Commons Attribution 4.0 International License (http://creativecommons.org/ licenses/by/4.0/), which permits unrestricted use, distribution, and reproduction in any medium, provided you give appropriate credit to the original author(s) and the source, provide a link to the Creative Commons license, and indicate if changes were made.

\section{References}

1. G. Zeng, S. McDonald, and K. Nogita, Development of HighTemperature Solders: Review, Microelectron. Reliab., 2012, 52, p 1306-1322

2. T. Gancarz, J. Pstrus, S. Mosinska, and S. Pawlak, Effect of $\mathrm{Cu}$ Addition to Zn-12Al Alloy on Thermal Properties and Wettability on $\mathrm{Cu}$ and Al Substrate, Metall. Mater. Trans. A, 2016, 47, p 368-377

3. T. Gancarz, J. Pstruś, P. Fima, and S. Mosinska, Effect of Ag Addition to $\mathrm{Zn}-12 \mathrm{Al}$ Alloy on Kinetics of Growth of Intermediate Phases on $\mathrm{Cu}$ Substrate, J. Alloys Compd., 2014, 582, p 313-322

4. W. Jurczak, Wpływ litu na właściwości i odporność korozyjną stopów Al-Zn-Mg w wodzie morskiej, Zeszyty Naukowe Akademii Marynarki Wojennej, ROK XLVI, nr, 2005, 3, p 162 (in Polish)

5. X. Yan, S. Liu, W. Long, J. Huang, L. Zhang, and Y. Chen, The Effect of Homogenization Treatment on Microstructure and Properties of ZnAl15 Solder, Mater. Des., 2013, 45, p 440-445

6. T. Savaskan and A. Hekimoglu, Microstructure and Mechanical Properties of Zn-15Al-Based Ternary and Quaternary Alloys, Mater. Sci. Eng., A, 2014, 603, p 52-57

7. T. Savaskan and A. Aydmer, Effects of Silicon Content on the Mechanical and Tribological Properties of Monotectoid-Based ZincAluminium-Silicon Alloys, Wear, 2004, 257, p 377-388

8. A. Vencl, I. Bobic, F. Vucetić, B. Bobic, and J. Ruzic, Structural, Mechanical and Tribological Characterization of $\mathrm{Zn} 25 \mathrm{Al}$ Alloys with Si and Sr Addition, Mater. Des., 2014, 64, p 381-392

9. L. Jian, E.E. Laufer, and J. Masounave, Wear in Zn-Al-Si Alloys, Wear, 1993, 165, p 51-56

10. F. Ji, S. Xue, J. Lou, Y. Lou, and S. Wang, Microstructure and Properties of $\mathrm{Cu} / \mathrm{Al}$ Joints Brazed with Zn-Al Filler Metals, Trans. Nonferrous Met. Soc. China, 2012, 22, p 281-287

11. L. Ma, D.Y. He, X.Y. Li, and J.M. Jiang, High-Frequency Induction Soldering of Magnesium Alloy AZ31B Using a Zn-Al Filler Metal, Mater. Lett., 2010, 64, p 596-598

12. Y. Jinlong, X. Songbai, X. Peng, L. Zhaoping, D. Wei, and Zh Junxiong, Development of Novel CsF-RbF-AlF3 Flux for Brazing Aluminium to Stainless Steel with Zn-Al Filler Metal, Mater. Des., 2014, 64, p 110-115

13. M. Prach and R. Kolenak, Soldering of Copper with High-Temperature Zn-Based Solders, Procedia Eng., 2015, 100, p 1370-1375

14. J. Pstrus and T. Gancarz, Interfacial Phenomena in $\mathrm{Al} / \mathrm{Al}, \mathrm{Al} / \mathrm{Cu}$, and $\mathrm{Cu} / \mathrm{Cu}$ Joints Soldered Using an Al-Zn Alloy with Ag or $\mathrm{Cu}$ Additions, J. Mater. Eng. Perform., 2014, 23, p 1614-1624

15. Y. Takaku, L. Felicia, I. Ohnuma, R. Kainuma, and K. Ishida, Interfacial Reaction Between $\mathrm{Cu}$ Substrates and $\mathrm{Zn}-\mathrm{Al}$ Base HighTemperature Pb-Free Solders, J. Electron. Mater, 2008, 37, p 314-323

16. T. Gancarz, J. Pstrus, P. Fima, and S. Mosinska, Thermal Properties and Wetting Behavior of High Temperature Zn-Al-In Solders, J. Mater. Eng. Perform., 2012, 21, p 599-605

17. T.J. Chen, C.R. Yuan, M.F. Fu, Y. Ma, Y.D. Li, and Y. Hao, Mater. Sci. Technol., 2008, 24, p 1321-1332

18. Z. Moser, P. Fima, K. Bukat, J. Sitek, J. Pstrus, W. Gasior, M. Koscielski, and T. Gancarz, Investigation of the Effect of Indium Addition on Wettability of Sn-Ag-Cu Solders, Solder. Surf. Mt. Tech., 2011, 23, p 22-29

19. S.M. Spearing, M.A. Tenhover, D.B. Lukco, L. Viswanathan, and D.K. Hollen, Models for Thermomechanical Behavior of Metal/Ceramic Laminates, Mat. Res. Soc. Symp. Proc., 1994, 323, p 128

20. E.A. Brandes, Ed., Smithells Metals References Book, VI, ed., Butterworth, London, England, 1983

21. J. Pstrus, P. Fima, and T. Gancarz, Wetting of $\mathrm{Cu}$ and $\mathrm{Al}$ by $\mathrm{Sn}-\mathrm{Zn}$ and Zn-Al Eutectic Alloys, J. Mater. Eng. Perform., 2012, 21, p 606-613

22. V. Raghavan, Al-Cu-Zn, J. Phase Equilib. Diff., 2007, 28, p 183-188 